\title{
WILAYAH PERBATASAN KALIMANTAN BARAT: SUMBER SEJARAH DAN PERMASALAHANNYA ${ }^{1}$
}

\author{
Djoko Marihandono ${ }^{2}$
}

\begin{abstract}
The research deals with the region in the two-area Kalimantan/Borneo border with Malaysia; in the east, Nunukan, and in the west, Entikong. The border problem rises when a geopolitical interest of Indonesia and Malaysia overwhelms the traditional ways of farming and trade that have existed even before the British and Dutch colonial governments executed their administrative systems by dividing them into security and prosperity belts, despite the existing active roles of local authorities to manage their resources. Now, the heritage of the rich natural resources and the mobile population, becomes a major issue of dispute. The available resources, such as fish, coal and gold; crops, such as chocolate, nutmeg and rubber; prospective reservation areas for tourism, such as the Indonesian national parks in Danau Sentarum, Gunung Niut, and Betung Karihun, become a vulnerable target for exploitation. These crucial zones have been a part of an intricate interwoven eco-region. The paper uses the colonial British and Dutch archieves and other literature to describe the historic conflict of interest for exploitation and extraction of the resources, and the post-independent sources which talked about the endless Malaysian intrusions faced by the Indonesian government.
\end{abstract}

Keywords

Border limits, traditional farming and trade, colonial archieves, geopolitics.

\section{LATAR BELAKANG}

Di Pulau Kalimantan, terdapat dua provinsi yang berbatasan dengan negara tetangga. Kedua provinsi itu adalah Kalimantan Timur dan Kalimantan Barat. Wilayah Provinsi Kalimantan Timur yang berbatasan dengan wilayah Malaysia adalah Kecamatan

\footnotetext{
${ }^{1}$ Makalah ini dengan judul yang berbeda, pernah disajikan pada acara kegiatan Kawasan (Kemah di Wilayah Perbatasan) yang diselenggarakan oleh kementerian Kebudayaan dan Pariwisata, tanggal 1721 Mei 2010 di Balai Latihan Kerja Entikong, Kabupaten Sanggau, Kalimantan Barat dan telah dilakukan revisi dan perbaikan seperlunya.

2 Penulis adalah pengajar tetap di Departemen Sejarah, Fakultas Ilmu Pengetahuan Budaya Universitas Indonesia. Aktivitas penulis selain mengajar, juga menjadi peneliti di Fakultas Ilmu Pengetahuan Budaya Universitas Indonesia.
} 
Nunukan di kabupaten Nunukan. ${ }^{3}$ Pelabuhan Nunukan merupakan akses terdepan di Kalimantan Timur untuk menuju ke kota Tawau, Malaysia. Sementara itu, wilayah Kalimantan Barat berbatasan kota Entikong dan berbatasan dengan wilayah Serawak, Malaysia. Batas terluar wilayah Provinsi Kalimantan Barat adalah Kecamatan Entikong ini, yang termasuk dalam wilayah Kabupaten Sanggau. Dari kedua kota kecamatan di Pulau kalimantan ini, kondisi sosial masyarakat di Kabupaten Sanggau dapat dikatakan lebih maju dibandingkan dengan wilayah perbatasan lainnya karena wilayah ini telah ditetapkan sebagai pos lintas batas resmi, seperti Entikong-Tebedu dan Nanga BadauLubuk Antu. Di samping pos lintas batas resmi, masih terdapat beberapa pos lintas batas tidak resmi, yaitu sekitar 50 jalur jalan setapak yang menghubungkan 55 desa di wilayah Kalimantan Barat dengan 32 kampung di Serawak. ${ }^{4}$ Secara geografis, sangatlah penting untuk mengetahui bahwa secara umum, panjang wilayah Kalimantan yang berbatasan dengan Negara Bagian Serawak sejauh $1.200 \mathrm{~km}$. Dari garis perbatasan sepanjang ini, kurang lebih 850 km berada di wilayah Kalimantan Barat, yang melintasi beberapa kabupaten, antara lain Sambas, Bengkayang, Sanggau, Sintang, dan Kapuas Hulu. Sementara itu, sisanya berada di wilayah Kalimantan Tengah dan Kalimantan Timur. Garis batas ini semula memiliki patok-patok perbatasan yang dipasang $20 \mathrm{~km}$ di belakang garis perbatasan, tetapi sebagian besar patok-patok ini telah rusak, atau bahkan telah hilang. Aktivitas perekonomian penduduk di wilayah perbatasan sebagian besar masih bersifat tradisional baik sektor pertanian maupun perdagangan. Namun, apabila ditinjau dari sumber daya alamnya, wilayah ini memiliki sumber daya alam yang berupa tambang batu bara yang terdapat di Senaning, dan tambang emas, yang berada di semua aliran sungai di sepanjang kawasan perbatasan. Sementara itu, potensi hutan terdapat di hutan lindung seperti Taman Nasional Danau Sentarum, Taman Nasional Gunung Niut, dan Taman Nasional Betung Karihun, yang sangat potensial dijadikan objek wisata alam. Potensi perikanan air tawar apabila dikembangkan memiliki potensi untuk dikembangkan, mengingat bahwa wilayah ini memiliki spesies ikan air tawar yang relatif lengkap, yang hanya terdapat di beberapa negara saja di dunia. Demikian pula potensi perkebunan rakyatnya. Penduduk setempat di kawasan ini menanam berbagai tanaman seperti coklat, lada, dan karet yang hasilnya dipasarkan ke Serawak. ${ }^{5}$ Ditinjau dari infrastrukturnya, kawasan perbatasan telah memiliki infrastruktur yang berupa

\footnotetext{
3 Berdasarkan Undang-Undang tanggal 4 Oktober nomor 47 tahun 1999, Kabupaten Nunukan ditetapkan menjadi kabupaten tersendiri yang merupakan pemekaran dari Kabupaten Bulungan. Berdasarkan undang-undang ini Kabupaten Bulungan dimekarkan menjadi dua kabupaten, yakni Kabupaten Nunukan dan Kabupaten Malinau.

4 Lihat Laporan Pemda Provinsi Kalimantan Barat yang berjudul Rencana Pembangunan dan Pengembangan Kawasan Perbatasan Kalimantan Barat, disampaikan oleh ketua Bappeda pada diskusi terbatas Pengembangan Kawasan Perbatasan Kalimantan, di Jakarta, 24 September 2001. Pontianak:Pemda Provinsi Kalimantan Barat.
}

5 Lihat Laporan Pemda Provinsi Kalimantan Barat hal. 9. 
sarana transportasi darat, laut, dan beberapa lapangan terbang perintis. Jalan darat yang menghubungkan wilayah di kawasan perbatasan terus bertambah, dengan perbandingan $63 \%$ jalan kabupaten, $31 \%$ jalan provinsi, dan sisanya jalan nasional. ${ }^{6}$ Dengan melihat potensi yang ada, sangatlah penting untuk membahas masalah-masalah yang muncul di wilayah perbatasan. Untuk memahami lebih mendalam tentang kawasan perbatasan ini, perlu dibahas terlebih dahulu sejarahnya. Untuk keperluan itu, diperlukan kajian arsip yang cukup lengkap dan akurat.

\section{SUMBER SEJARAH WILAYAH PERBATASAN KALIMANTAN}

Telah terbit beberapa buku yang membahas wilayah perbatasan itu, baik yang disusun oleh lembaga pemerintah maupun swasta, dari kalangan perguruan tinggi maupun pribadi. Dari sekian banyak buku tentang wilayah perbatasan, terdapat dua buku yang terbit pada tahun 2009, yaitu buku Satu Selat Dua Nahkoda, dan Satu Ruang Dua Tuan, yang diterbitkan oleh Gramata Publishing. ${ }^{7}$ Buku ini membahas wilayah perbatasan antara Batam-Singapura dan wilayah perbatasan Entikong-Malaysia. Kedua buku diterbitkan dengan memanfaatkan dokumen asli, dari sumber arsip hingga sumber terbitan sezaman.

Dalam penelitian sejarah, sumber arsip sering disebut sebagai sumber primer, sementara terbitan sezaman disebut sebagai sumber sekunder. Yang dimaksudkan sebagai sumber sekunder adalah tulisan yang berhubungan dengan tema atau topik penelitian yang telah ditulis orang sebelumnya. Di pusat penyimpanan arsip (termasuk di Arsip Nasional Republik Indonesia), dikenal dua kelompok besar arsip, yakni arsip kolonial dan arsip republik. Pengelompokan ini didasarkan pada pertimbangan adanya garis pemisah yang sangat besar dari kajian kronologis sejarah Indonesia, yakni era kolonial dan era kemerdekaan. Pada era prakemerdekaan, wilayah Nusantara ini pernah dikuasai oleh beberapa kekuasaan asing, seperti Portugis, Spanyol, Prancis, Inggris, Belanda, dan Jepang. Tiap-tiap penggalan waktu ini meninggalkan arsip yang dikelompokkan menjadi arsip kolonial. Sementara itu, penggalan waktu kemerdekaan dan pasca-kemerdekaan dikelompokkan menjadi arsip pasca kemerdekaan. Dengan demikian, di kalangan sejarawan Indonesia, sangatlah sering terdengar istilah arsip periode kolonial dan periode kemerdekaan.

Untuk mengkaji wilayah perbatasan di Kalimantan, diperlukan beberapa arsip yang disimpan di Arsip Nasional republik Indonesia, di jalan Ampera Raya, Jakarta. Di

\footnotetext{
${ }^{6}$ Menurut laporan Ketua Bappeda, jalan yang ada lebih berbentuk vertikal ke arah garis perbatasan, sehingga kurang efektif baik sebagai sabuk pengaman (security belt) maupun sebagai sabuk kesejahteraan (prosperity belt). Sementara itu jaringan jalan di Serawak berbentuk horizontal sejajar dengan garis perbatasan, sehingga memudahkan dalam pelaksanaan monitoring, pengamanan, maupun pengembangan wilayah perbatasan.

${ }^{7}$ Dalam buku ini ditulis berdasarkan pada arsip-arsip kolonial tentang kedua wilayah itu.
} 
pusat penyimpanan arsip ini diperlukan arsip yang tersimpan dalam bundel West Borneo. Dalam bundel ini ditemukan sejumlah arsip yang mencatat secara kronologis seperti Politiek Verslag van Residentie West Borneo, Algemeen Verslag van Residentie West Borneo, dan Administratief Verslag van Residentie West Borneo. Informasi yang diperoleh dalam bundel West Borneo berupa laporan setiap tahun yang dikirimkan oleh Kepala Daerah Borneo Barat atau pejabat yang menggantikannya kepada pemerintahan pusat di Batavia, baik kepada gubernur jenderal ataupun kepada pejabat lainnya. Semua kegiatan rutin, baik berupa aktivitas pemerintahan, aktivitas penduduk, jumlah penduduk, hasil bumi yang dikumpulkan dan dilaporkan kepada pemerintah daerah, maupun kejadian ataupun peristiwa yang terjadi di Borneo Barat, ditemukan dalam bundel ini. Dari bundel ini, peneliti dapat menemukan semua peristiwa yang terjadi di Borneo Barat secara kronologis dengan segala aspeknya, baik aspek politik, keamanan, sosial, maupun budayanya.

Di pusat penyimpanan arsip Arsip Nasional Republik Indonesia juga dapat dijumpai bundel arsip tentang Keresidenan wilayah Borneo Timur dan Selatan, yang terdapat pada bundel Afdeeling Oost en Zuid Borneo Residentie. Dalam bundel ini disimpan dua cakupan wilayah, yaitu Kalimantan Barat dan Kalimantan Timur (bila dilihat dari kondisi saat ini) karena wilayah ini kini menjadi bagian dari Provinsi Kalimantan Timur. Dalam bundel Afdeeling Oost en Zuid Borneo Residentie ini yang menjadi keistimewaan adalah pengertian Oost en Zuid Borneo. Dalam arsip ini yang termasuk dalam wilayah Oost en Zuid Borneo adalah batas yang termasuk dalam wilayah Hindia Belanda dan Crown Colony Inggris di Borneo Utara.

Secara garis besar, isi dari kedua bundel ini adalah kegiatan pemerintah kolonial Belanda dari abad XIX sampai dengan abad XX. Kegiatan pemerintah kolonial Belanda di wilayah ini dimulai pada awal abad XIX. Pada akhir abad ini dan memasuki abad XX sebagai konsekuensi dari Decentralisatie Wet yang diputuskan dari Belanda dan dilanjutkan oleh semua wilayah di bawah pemerintahan pusat di Batavia. Dengan adanya Decentralisatie Wet terjadi reorganisasi pemerintahan yang berakibat pula pada perubahan sistem korespondensi pada masa itu. Para kepala wilayah tidak lagi diwajibkan untuk melaporkan apa yang telah dilaksanakan dan apa yang direncanakan pada tahun berikutnya setiap tahun, seperti halnya sebelum diberlakukannya Decentralisatie Wet, tetapi para kepala wilayah itu cukup hanya mengirimkan laporan pada masa akhir jabatan mereka, yang digabungkan dalam Memorie van Overgave (laporan serah terima jabatan). Dalam laporan ini (yang sering disebut sebagai $\mathrm{MvO}$ ), yang dilaporkan adalah semua peristiwa dan kejadian yang terjadi selama masa pemerintahan seseorang pejabat, lengkap dengan semua aspek dan akibat dari kebijakan yang diambilnya. Laporan ini dikirimkan ke Batavia sebagai laporan pertanggungjawaban mantan pemimpin daerah. Setelah pusat menerima laporan ini, pejabat di Batavia menyerahkannya kepada pejabat yang baru, yang kemudian akan digunakan sebagai dasar dari kebijakan yang akan diambilnya. Kebanyakan laporan ini berisi informasi yang cukup akurat mengingat bahwa laporan ini merujuk langsung pada 
peristiwa di daerah yang menjadi wewenang pejabat itu.

Dalam koleksi Algemeen Secretarie, yang juga disimpan di Arsip Nasional Republik Indonesia, terdapat dua periode dari bundel arsip algemeen Secretarie ini. Periode pertama adalah laporan sekretaris umum dari tahun 1816 sampai dengan 1891, sementara yang kedua adalah periode 1891 sampai dengan 1942, tatkala Jepang menguasai Nusantara ini. Pembagian periode ini didasarkan atas pembagian wewenang dalam birokrasi pemerintah kolonial di Sekretariat Umum (Algemeen Secretarie) sebagai lembaga yang bertanggung jawab atas pengumpulan dan penyimpanan arsip-arsip negara. Mengingat bahwa pusat penyimpanan arsip di Jakarta ini pernah mengalami perpindahan tempat penyimpanan, arsip periode pertama disebut sebagai Algemeen Secretarie Gadjah Mada karena arsip ini sebelumnya disimpan di Pusat Arsip Nasional yang terletak di jalan Gadjah Mada, Jakarta. Sementara itu, arsip dari periode kedua dikenal dengan Algemeen Secretarie Bogor karena bundel ini disimpan di pusat penyimpanan arsip, Arsip Nasional Republik Indonesia, di Kota Bogor. Dalam bundel ini banyak ditemukan arsip penting, khususnya Surat Keputusan Gubernur Jenderal (Besluit van Gouverneur Generaal), Agenda, Missives van Gouvernement Secretarie, Brief van Gouvernement Secretaris, Komissarial dan Renvooi. Isi arsip ini bersifat sangat rahasia pada masa itu, yang merupakan laporan atau informasi pertama yang sangat menentukan terjadinya suatu peristiwa. Dalam bundel ini dapat diketahui proses dikeluarkannya suatu keputusan, perimbanganpertimbangan atas munculnya keputusan itu, dan semua alasan lain yang mendasari dikeluarkannya surat keputusan tertentu. Semua berkas yang tersimpan dalam bundel ini berasal dari Batavia sebagai pusat kekuasaan di Hindia Belanda, terdiri atas surat-surat atau korespondensi dari kepala wilayah kepada pemerintah daerah yang tembusannya dikirimkan ke pemerintah pusat.

Dari sekian banyak arsip yang ada, perlu pula dibuka arsip yang terkumpul dalam koleksi Politiek Verslag van Buitengewesten. Koleksi ini merupakan koleksi arsip abad XX, tepatnya tahun 1927-1942. Dalam laporan yang berasal dari intelijen dari dinas militer ini dapat diketahui kondisi politik tiap-tiap keresidenan di luar Jawa, termasuk Borneo (Borneo Barat, Borneo Timur dan Borneo Tenggara). Laporan ini dibuat enam bulan sekali, yang berisi tentang peristiwa politik seperti aktivitas partai, aktivitas organisasi masa, aktivitas elite tokoh politik lokal, pers lokal, aliran politik, soaial dan keagamaan, dan informasi lain baik yang mendukung maupun mengancam kelangsungan pemerintah kolonial di wilayah itu.

Selain arsip, seperti yang telah disebutkan sebelumnya, arsip sezaman dapat digunakan sebagai informasi pendukung. Arsip sezaman, yang berupa penerbitan tulisan sezaman dengan tema yang akan diteliti, sangat penting untuk mendukung data yang diperlukan dan dapat digunakan sebagai pegangan tentang pandangan dari masyarakat (anggota maupun tokohnya) tentang suatu peristiwa atau suatu kebijakan yang telah diputuskan oleh pemerintah kolonial. Untuk wilayah perbatasan di Kalimantan (baca: 
Borneo) dapat digunakan surat kabar terbitan Banjarmasin, Riau, dan Pontianak. Ketiga surat kabar ini diasumsikan memiliki kedekatan wilayah dengan perbatasan Borneo yang dikuasai oleh Inggris dan Belanda. Selain koran, masih terdapat beberapa artikel lain yang dimuat di majalah-majalah Hindia Belanda seperti: TNI (Tijdschrift voor Nederlandsch Indie, Indische Gids, de Gids, TBB (Tijdschrift voor Binnenlandsch Bestuur).

\section{SEJARAH KOLONIAL INGGRIS DI BORNEO}

Pada tanggal 17 Maret 1824, telah terjadi suatu peristiwa yang di kemudian hari sangat mempengaruhi perkembangan kolonialisme Eropa di Nusantara. Pada tanggal itu telah ditandatangani Traktat London II. Traktat London II ini merupakan penyempurnaan dari Traktat London I yang telah ditandatangani sebelumnya pada tanggal 13 Agustus 1814. Dalam Traktat London I ini isinya banyak mengatur tentang pengembalian garis batas wilayah negara-negara Eropa dan koloninya pada masa sebelum pemerintahan Napoléon Bonaparte. Namun demikian, dalam Traktat London I ini juga diatur pengembalian wilayah kolonial Hindia Belanda bekas wilayah VOC yang dikuasai oleh Inggris kepada pemerintah Belanda. ${ }^{8}$

Pada peristiwa itu telah tercapai kesepakatan antara delegasi Belanda yang dipimpin oleh Baron Henry Fagel dan Anton Reinhard Falck dan delegasi Inggris yang diwakili oleh George Canning dan Charles Warkin William Wynn. Kesepakatan antara dua delegasi ini dikenal dengan Traktat London II. Traktat ini mengakhiri perselisihan yang terjadi antara pemerintah kolonial Inggris dan Belanda yang masing-masing mengakui wilayah mereka masing-masing di Asia Tenggara. Salah satu pasal yang disepakati dalam perjanjian itu antara lain disepakatinya secara tegas garis perbatasan secara tegas. Kedua belah pihak sepakat dan setuju menetapkan bahwa Singapura dijadikan wilayah kekuasaan Inggris, yang telah dikuasainya sejak tahun 1819. Berdasarkan kesepakatan itu, tiap-tiap pemerintah kolonial (baca: Inggris dan Belanda) menarik batas masing-masing sesuai kesepakatan mereka. Dari perjanjian itu, pemerintah kolonial Inggris melepaskan beberapa wilayah yang semula berada di bawah kekuasaan Belanda seperti Bengkulu, Bangka, dan Belitung, sementara pihak pemerintah kolonial Belanda melepaskan wilayah Malaka dan Masulitpam di Hindia. Untuk sementara waktu, masalah di antara dua pemerintah kolonial Eropa ini selesai. Namun, hal itu hanya berlangsung dalam waktu yang pendek. Penafsiran atas isi perjanjian itu diinterpretasikan tersendiri sesuai kepentingan masing-masing. Perbedaan interpretasi itu akhirnya terbawa juga ke wilayah koloni di Nusantara ini. Sebagai contoh, intrik-intrik politik dan tindakan para pejabat kolonial Inggris dan Belanda di Sumatera setelah pengembalian kekuasaan

\footnotetext{
8 Isi Traktat London II dimuat selengkapnya dimuat dalam Staatsblad van nesderlandsch Indie over het jaar 1825 nomor 19, dan dalam JW Norie, 1827. Naval Gazetteer, Biographer and Chronologists, halaman: 575577. London: JW Noorie\&co.
} 
wilayah itu ke Belanda. Tindakan Raffles dan pejabat di Batavia memicu terjadinya konflik yang baru, yang berdampak pada seluruh wilayah Sumatera dan Malaya. ${ }^{9}$

Permasalahan lain timbul khususnya dengan wilayah-wilayah yang berada di sekitar perbatasan yang masih merdeka, bebas dari kekuasaan kolonial mana pun, seperti Kesultanan Aceh, Riau, dan Borneo. Kondisi Kesultanan Aceh pada waktu perjanjian itu ditandatangani masih bebas, belum berada di bawah penguasa kolonial mana pun bebas melakukan aktivitasnya, termasuk di dalamnya aksi perompakan di laut, yang banyak dilakukan oleh orang-orang Aceh. Keluhan yang datangnya dari pusat di Batavia tentang banyaknya korban prompakan laut di selat Malaka tidak dapat diatasi mengingat bahwa wilayah Aceh berada di bawah Singapura yang saat itu berada di bawah kekuasaan pemerintah kolonial Inggris. Sementara itu, wilayah perairan Riau, yang menjadi ajang perampokan oleh orang-orang Bugis tersebar di Kepulauan Riau ini. Perompakan yang dilakukan oleh orang Aceh berbeda motivasinya bila dibandingkan dengan perompakan di wilayah kepulauan Riau. Para perompak Bugis ini mencampurkan antara aktivias perompakan dan aktivitas politik, yaitu menginginkan menjadi suatu kelompok yang dominan di mata raja-raja Melayu, demi kepentingan orang Bugis, bantuan akan mudah mereka peroleh dari Raja-Raja Melayu. Kelompok Bugis ini berhasil menggantikan penguasa Melayu dan bahkan menjadi raja di beberapa wilayah tersebut. Konsekuensinya, pemerintah kolonial Belanda harus menghadapi mereka, terutama kekuatan politik rajaraja kecil di wilayah itu. ${ }^{10}$

Selain kedua wilayah itu, di Pulau Borneo juga terjadi keresahan yang terjadi di kalangan raja-raja yang dominan di pulau itu. Pemerintah di Batavia tidak berusaha secara serius untuk menegakkan kekuasaan di pulau ini. Hubungan yang terjadi di wilayah ini hanya sekadar kesepahaman untuk saling menghormati antara pemerintah pusat di Batavia dan raja-raja pribumi yang dominan. Tidak ada kesepakatan khusus dengan mereka, apalagi perjanjian-perjanjian khusus. Dengan kondisi semacam itu, Sultan menjadi penguasa tertinggi di wilayahnya, yang mendasarkan sistem pemerintahannya pada agama Islam, dengan Alquran sebagai dasarnya.

Walaupun belum terjadi kesepakatan dengan pihak penguasa kolonial Eropa, para raja di pulau ini telah memperoleh pengaruh dari kekuasaan Kesultanan Sulu di Filipina Selatan sejak abad XVI. Dengan kekuasaanya yang besar, Sultan Sulu berhasil memengaruhi Sultan Brunei yang memeluk agama Islam sebagai akibat dari pengaruh Sultan Sulu. Dengan dukungan Kesultanan Sulu, Kesultanan Brunei dapat menegakkan kekuasaannya atas wilayah Brunei dan Borneo bagian Utara pada abad XVIII. Sejalan dengan melemahnya kekuasaan Kesultanan Sulu, Kesultanan Brunei tampil sebagai

\footnotetext{
${ }_{9}$ Lihat J. Paulus dalam Encyclopaedia van Nederlandsch Indie, Eerste Deel. S'Gravenhage, 1918, Martinus Nijhoff, 676-679.

${ }^{10}$ Lihat Christian Pelras, 1996. The Bugis (Oxford, Blackwell), 307.
} 
penguasa dominan di wilayah Borneo Utara. Seperti layaknya penguasa di wilayah lain, penguasa wilayah Brunei menjalin hubungan politik dan ekonomi dengan rajaraja pribumi lainnya di Borneo. Sebagai akibat dari ekspansi politiknya itu, banyak raja kecil Borneo yang menguasai suku-suku Dayak kemudian tunduk kepada Sultan Brunei. Dengan kondisi semacam ini, kehidupan politik di Borneo sejak abad XVIII didominasi oleh Sultan Brunei, yang terdesentralisasi pada kesultanan-kesultanan kecil, yang berada di bawah kekuasaan Kesultanan Brunei.

Bagi pemerintah kolonial, baik Inggris maupun Belanda, pulau Borneo merupakan terra incognita 'tanah yang tidak dikenal'. Hal ini disadari sepenuhnya oleh para penguasa Eropa karena pulau itu berupa gunung-gunung yang ditutupi oleh hutan liar yang sulit untuk diekspansi. Dari pengalaman para petualang, diketahui pula bahwa pulau itu masih dihuni oleh penduduk liar yang tidak segan-segan untuk membunuh para pendatang yang dianggap sebagai musuhnya. Oleh karena itu, hingga abad XIX, para penguasa di Batavia masih memperlakukan pulau Borneo sebagai wilayah yang para rajanya harus melakukan penyerahan wajib (verplichte Leverantie) kepada penguasa kolonial di Batavia sebagai akibat dari kontrak-kontrak yang mereka buat sebelumnya.

Menjelang paruh kedua abad XIX, tatkala pemerintah di Batavia dan pemerintah di Singapura tidak memperhatikan pulau itu, tibalah seorang pelaut Inggris yang bernama James Brooke yang mendarat di pulau ini. ${ }^{11}$ Ia memperoleh informasi bahwa pulau Borneo memiliki kandungan mineral yang sangat kaya, yang saat itu menjadi primadona komoditi di dunia. Ia telah mengetahui bahwa tambang emas dan intan di pulau itu telah dieksploitasi oleh orang Cina sejak tahun 1750. Ia pun mencari tambang lain yang tidak kalah menjanjikan untuk memperoleh keuntungan yang besar. Akhirnya ia memutuskan untuk mencari tambang bijih besi yang berdasarkan penyelidikannya banyak terdapat di wilayah Serawak.

Kedatangan James Brooke ke Serawak bersamaan dengan terjadinya pemberontakan suku-suku Dayak di pedalaman Borneo terhadap penguasa di Serawak. Pangeran Hasim sebagai vasal Sultan Brunei tidak dapat mengatasi pemberontakan ini karena tidak memperoleh bantuan dari Sultan Brunei. Ia kemudian meminta bantuan kepada James Brooke yang bersedia membantu menyediakan senjata dan amunisi, bahkan bila diperlukan bantuan tentara apabila ia diberikan konsesi untuk mengeksplorasi tambang bijih besi di Serawak. Dengan bantuan yang diberikan oleh James Brooke, Pangeran Hasim berhasil memadamkan pemberontakan suku Dayak. Namun, tidak lama kemudian, Pangeran Hasim melarang James Brooke untuk mengeksploitasi tambang bijih besi. Akibat keputusan sepihak ini, James Brooke berhasil memaksa Pangeran Hasim turun dari takhta pada tanggal 21 September 1841 melalui kekuatan

\footnotetext{
11 Tidak ada keterangan pasti tentang James Brooke ini, apakah ia seorang pedagang, seorang pelaut atau pegawai kongsi dagang Inggris EIC (East India Company).
} 
senjata. Dengan diturunkannya Pangeran Hasim, James Brooke mengangkat dirinya sebagai penggantinya, tetapi ia tidak mau tunduk pada Sultan Brunei. Oleh karena itu, ia mengangkat dirinya sebagai Raja Serawak. Sejak saat itu Serawak menjadi kerajaan yang merdeka dengan James Brooke sebagai rajanya. ${ }^{12}$

Dengan posisinya ini, kedudukan James Brooke sangat berisiko karena akan berhadapan dengan tiga kekuatan yang berada di hadapannya, yakni Sultan Brunei, pemerintahan EIC, dan pemerintahan di Batavia. Karena risiko yang sangat besar mungkin terjadi, ia memutuskan untuk menjadi vasal Sultan Brunei seperti Pangeran Hasim. Untuk itu, ia berjanji akan mengirimkan upeti sebesar 2.000 dolar setiap tahun kepada Sultan Brunei. Karena adanya janji tersebut, Sultan Brunei tidak jadi melakukan penyerangan ke Serawak. Namun pada tahun 1845, James Brooke menghentikan pengiriman upetinya tatkala Sultan Brunei menghadapi masalah internal di kesultanannya. Dengan kondisi Sultan Brunei yang makin melemah, James Brokke kembali tahun 1845 menyatakan dirinya sebagai penguasa atas wilayah Serawak yang merdeka.

Berkat upaya James Brooke dalam membantu membebaskan para pedagang Inggris dari ancaman kaum perompak, dan atas jasanya mendukung pemerintah dan kehadirannya di Serawak sangat menguntungkan Inggris, akhirnya pemerintah EIC di Calcutta mengakui keberadaan James Brooke di Serawak. Pada tahun 1846, Sultan Brunei memerlukan bantuan James Brooke. Sultan menjanjikan akan memberikan Pulau Labuan kepada James Brooke sebagai imbalan dari bantuan yang diberikan oleh James Brooke. Akhirnya, James Brooke menyerahkan pulau itu kepada pemerintah Inggris. Sejak itu pulau itu menjadi berada di bawah kekuasaan Inggris. Sebagai imbalan atas jasanya itu, pemerintah Inggris di London dan penguasa EIC di Calcutta mengakui eksistensi James Brooke dan memberikan gelar kebangsawanan kepadanya dengan nama Sir James Brooke. Gelar ini berhak ia gunakan dan ia serahkan kepada keturunannya. Dengan situasi seperti itu, dinasti Brooke mulai memerintah di Serawak. Brooke berpandangan bahwa sangatlah penting melibatkan masyarakat tradisional dalam pemerintahannya. Oleh karena itu, sejak awal berdirinya dinasti Brooke di Serawak, tidak pernah terjadi perlawanan rakyat terhadap dinasti Brooke, hingga pemerintah Inggris mengambil alih wilayah ini sebagai koloni Inggris.

Meskipun tidak mendapatkan perlawanan dari masyarakat pribumi, James Brooke justru mendapatkan serangan dari pemerintah Koloni Hindia Belanda yang berpusat di Batavia dan negara induknya di Den Haag karena peristiwa ini dianggap bertentangan dengan kesepakatan Traktat London tahun 1824. Menteri Perdagangan dan Koloni JC Baud mengirimkan surat perintah kepada Gubernur Jenderal Rochussen agar segera melakukan penyelidikan dan mengambil langkah seperlunya guna mencegah tindakan James Brooke.

${ }_{12}$ Lihat W.Stapel. 1940. Geschiedenis van Nederlandsch Indie, jilid V. (Amsterdam, NV. Uitgeversmaatschappij, 298. 
Menyikapi reaksi Den Haag atas peristiwa itu, pemerintah di London mengajak Den Haag untuk mendiskusikan masalah itu. Namun, setelah dilakukan penelitian dokumen, pejabat Belanda baru sadar bahwa mereka telah mengabaikan wilayahwilayah perbatasan, termasuk perbatasan Borneo. Bahkan Gubernur Jenderal Rochussen mengakui bahwa di Batavia, dokumen yang berkaitan dengan wilayah perbatasan hampir tidak ditemukan. ${ }^{13}$ Dengan kondisi semacam itu, pemerintah Hindia Belanda tidak dapat berbuat banyak tatkala melihat kekuasaan Inggris berdiri kokoh di Borneo Utara. Baru pada tanggal 28 Februari 1846, pemerintah di Batavia mengeluarkan pengumuman tentang batas-batas wilayah kekuasaannya. Tiga tahun kemudian, tepatnya tahun 1849, pemerintah secara resmi mengeluarkan pengumuman mengenai batas wilayah dalam Staatblad van Nederlandsch Indie over het jaar 1849 nomor 40.

Untuk mempertegas batas wilayahnya, pemerintah kolonial Belanda mendapatkan banyak kesulitan untuk menetapkan batas wilayah itu, karena wilayah itu masih dikuasai oleh raja-raja kecil. Dengan kekuatan senjata dan pendekatan diplomatik, akhirnya pemerintah kolonial Belanda dapat memperjelas daerah kekuasaannya. Untuk memperjelas perbatasan wilayah itu, dikirimkan seorang ahli yang bernama Profesor Oudemans ke Borneo Utara untuk menentukan batas wilayah yang pasti. Oudemans mengusulkan kepada Gubernur Jenderal P. Mijer di Batavia untuk menetapkan garis batas antara wilayah Belanda dan Sultan Brunei adalah 4019'57" Lintang Utara dan 117044'52" Bujur Timur. Titik itu apabila dilihat dengan kenyataan di lapangan berada pada sungai Sebuku. Pengukuran hidrografi yang dilakukan pada tahun 1877, menetapkan bahwa wilayah Belanda terdapat pada $4^{0} 19^{\prime}$ Lintang Utara dan 118023'30" Bujur Timur. Batas itu berada pada Sungai Belikan dan Sungai Naga yang dalam peta tahun 1877 bernama sungai Sebuku. Setelah diketahui batas-batas wilayah itu, pemerintah kolonial Belanda mulai melakukan penguasaan atas wilayah raja-raja kecil yang berada di sekitar perbatasan: seperti dengan Sultan Sambas (23 Agustus 1878), penguasa Sanggau, Tayan, dan Suhai (kontrak tahun 1855). Ketegangan dengan pemerintah kolonial Inggris mulai terjadi pada tahun 1881 tatkala pemerintah kolonial Inggris menyatakan bahwa wilayah Borneo Utara menjadi wilayah protektorat Inggris. Hal ini terjadi karena kekhawatiran dari pihak Belanda akan terjadinya infiltrasi dalam upaya menjalin hubungan dengan penguasa pribumi di Borneo, yang bila dibiarkan akan merugikan pemerintah di Batavia.

\section{KONFRONTASI DENGAN MALAYSIA}

Secara politis, kontak pertama antara pemimpin Indonesia dan pemimpin tokoh Malaya terjadi pada zaman Jepang, yaitu antara Soekarno dan Ibrahim Bin Yacob.

\footnotetext{
${ }^{13}$ Menurut Stapel (1940), di Batavia hanya ditemukan satu berkas dokumen yang berhasil dikumpulkan oleh Baud, yang kemudian dimuat dalam Corpus Diplomaticum Neerlando Indicum, 'Data Diplomatik Hindia Belanda' yaitu kontrak yang dibuat antara Sultan Kutai dan Pemerintah Kolonial Belanda tanggal 11 Oktober 1844.
} 
Pertemuan ini tidak hanya merupakan pertemuan pribadi kedua tokoh itu, tetapi lebih merupakan pertemuan politis dalam upaya pembentukan ikatan politik bersama. Dasar dari ikatan yang akan dibentuk adalah persamaan rumpun dan senasib sebagai bangsa koloni. Berdasarkan ikatan serumpun dan senasib ini muncul ide dan semangat untuk menggerakkan kerja sama dan konsep Indonesia Raya yang digagas oleh Soekarnolah yang diharapkan menjadi wadahnya. Meskipun akhirnya wadah ini tidak melibatkan Malaya, hubungan dan simpati tetap berlangsung hingga kedua negara memperoleh kemerdekaannya.

Setelah menerima pengakuan kemerdekaan dari Belanda (1949), pemerintah Republik Indonesia berupaya untuk menjalin hubungan dengan bangsa-bangsa lain di dunia, meskipun saat itu Malaya masih berada di bawah dominasi Inggris. Bahkan, tatkala Indonesia diterima menjadi anggota Perserikatan Bangsa-Bangsa, dukungan diberikan oleh Malaya sebagai pengakuan atas eksistensi Republik Indonesia di kancah negara-negara lain di dunia. Dukungan kepada Republik Indonesia tatkala pemerintah berhasil menggelar Konferensi Asia-Afrika pada bulan April tahun 1955. Dukungan terhadap pemerintah tercermin dari anggota sidang yang berasal dari wakil negaranegara yang baru merdeka dan yang akan merdeka. Indonesia dianggap sebagai ikon perlawanan terhadap kolonialisme dan imperialisme. Di balik kesuksesannya di mata negara-negara Asia Afrika, Soekarno menghadapi berbagai macam kesulitan yang datangnya dari dalam negeri. Soekarno kemudian mengalihkan perhatiannya pada masalah Papua dengan membekukan semua aset dan perusahaan Belanda yang berada di Indonesia. Walaupun dengan susah payah, dibarengi dengan suasana perang dingin, Soekarno mampu membawa bangsanya dari kemelut dalam negeri yang sangat berat.

Selanjutnya, perkembangan di dunia internasional memperkeruh hubungan antara Indonesia dan Malaya. Pemerintah Inggris berencana akan memberikan kemerdekaan kepada Malaya dan menempatkannya sebagai negara anggota Persemakmuran Bersama (commonwealth) yang langsung berada di bawah pemerintahan Inggris Raya. Bentuk negara yang akan diberikan adalah Federasi Malaya yang terdiri atas Semenanjung Malaya dan Singapura. Setelah melalui pembicaraan yang cukup panjang, akhirnya pada tanggal 31 Juli 1957, parlemen Inggris memutuskan untuk memberikan kemerdekaannya kepada bekas wilayah koloninya, yaitu Malaya dan Penang.

Tidak semua warga Malaya menyambut gembira keputusan dari parlemen Inggris. Sebagian dari mereka menghendaki berdirinya negara tersendiri, merdeka tanpa campur tangan Inggris. Akhirnya pemerintah Inggris mengambil jalan tengah dengan memisahkan Malaya dan Singapura. Singapura memperoleh konstitusi baru pada bulan Mei 1958, dan pemberian status negara kota pada tanggal 3 Juli 1959.

Setelah pemberian kemerdekaan kepada Singapura, pemerintah Inggris merencanakan untuk memberikan kemerdekaan kepada Malaya. Tengku Abdul Rahman akan ditunjuk sebagai pemimpin baru Malaya. Ia menyampaikan pidatonya di 
depan Foreign Correspondents Association di Singapura. Dalam pidatonya itu, ia akan membentuk Federasi Malaya yang terdiri atas Malaya, Singapura, dan koloni Inggris di Kalimantan Utara (Sabah dan Serawak). Gagasan ini ditolak oleh Barisan Sosialis Malaya, dengan tuduhan adanya tujuan khusus dari pihak Inggris di balik rencana itu, yang menyebabkan kelompok itu menyampaikan pernyataannya di Kuala Lumpur pada bulan Januari 1972, yang intinya menolak rencana Federasi Malaya. Demikian pula di Singapura, muncul kelompok yang menentang gagasan federasi itu. ${ }^{14}$

Bersamaan dengan rencana pembentukan federasi itu, di Kalimantan Selatan timbul kerusuhan. Rencana Inggris untuk membentuk federasi dianggap oleh Soekarno akan mengancam eksistensi Indonesia. Dari sinilah pemecahan wilayah Kalimantan dilakukan. Soekarno membagi wilayah kalimantan menjadi tiga provinsi, yakni Kalimantan Timur, Kalimantan Selatan dan Kalimantan Barat. Untuk menjaga kemungkinan gangguan yang datangnya dari luar, Soekarno membentuk Tentara Teritorial yang memiliki kekuasaan untuk memegang komando atas seluruh wilayah di Kalimantan. Bahkan Soekarno juga memberikan wewenang kepada Tentara Teritorial ini untuk mengambil alih kekuasaan apabila diperlukan. Langkah politik penting lainnya adalah membentuk provinsi baru, yaitu Provinsi Kalimantan Tengah yang sebelumnya menjadi bagian dari Provinsi Kalimantan Selatan. ${ }^{15}$

Soekarno juga memiliki kecurigaan terhadap Inggris yang melakukan langkahlangkah terencana, seperti menghubungkannya dengan krisis di Papua, menuduh negara lainnya membantu Belanda, dan upaya rekayasa ekonomi oleh Inggris terhadap negara yang baru berdiri ini, karena modal Inggris sangat dominan di Malaya, yang suatu saat menurut Soekarno akan merambat ke Kalimantan. Untuk alasan itulah Soekarno melancarkan protes ke Kuala Lumpur. Sementara itu, Kuala Lumpur menuduh Soekarno melakukan intervensi terhadap urusan dalam negeri Malaysia, yang menyebabkan timbulnya protes di kantor perwakilan RI di Kuala Lumpur yang disertai dengan demontstasi. Pada tanggal 3 Mei 1963, Soekarno menerima laporan itu, yang menyebabkan kemarahan yang luar biasa. Saat itu juga Soekarno mengumumkan Komando Dwikora untuk memprotes penguasa Malaya untuk membatalkan Federasi Malaysia. Tengku Abdul Rahman memberikan reaksi atas ultimatum Soekarno dengan menyampaikan pidatonya pada bulan Juli 1963 yang intinya tetap melanjutkan program tersebut. Akibat dari pidato Tengku Abdul Rahman, pada tanggal 23 Juli 1963 Soekarno secara resmi menyatakan Konfrontasi dengan Malaysia dengan memberikan komando "Ganyang Malaysia".

Di tengah terjadinya krisis antara Malaysia dan Indonesia, Presiden Filipina

\footnotetext{
${ }^{14}$ Lihat Triana Wulandari, 2009 Satu Ruang Dua Tuan (Gramata Publishing) bab III, 59-88.

${ }_{15}$ Pembentukan Provinsi Kalimantan Tengah didasarkan atas Undang-Undang Darurat nomor 10 tahun 1957.
} 
Diodados Macapagal melancarkan protes terhadap Malaysia yang mencantumkan Sabah dan Serawak dalam Federasi Malaysia. Macapagal menuntut bahwa wilayah itu merupakan bagian dari Republik Filipina, yang semula merupakan bagian dari Kesultanan Sulu. Ketegangan ini menurun intensitasnya setelah diselenggarakannya pembicaraan segitiga tingkat kepala negara dengan tujuan untuk membuat komunikasi politik di antara ketiga pemimpin negara yang terlibat (Maphilindo).

Ketika persiapan pertemuan puncak antara ketiga pemimpin negara yang terlibat ini dilakukan, Tengku Abdul Rahman mengumumkan terbentuknya Federasi Malaysia pada tanggal 31 Agustus 1963 yang diyakininya akan mendapatkan dukungan penuh dari negara persemakmuran. Keyakinannya itu terlaksana tatkala Malaysia mendapatkan dukungan dari Inggris. Dukungan Inggris ini mengakibatkan munculnya dukungan dari negara-negara lain sehingga Malaysia diterima menjadi anggota PBB bahkan dijadikan Dewan Keamanan Tidak Tetap PBB pada awal tahun 1944. Hal inilah yang menyebabkan Soekarno berang sehingga ia memutuskan keluar dari PBB dengan membentuk organisasi dunia baru New Emerging Forces (NEFO).

Situasi kritis ini menyebabkan pasukan Indonesia berhadapan dengan pasukan Malaysia yang didukung oleh pasukan Inggris, Australia, dan Selandia Baru di perbatasan Kalimantan. Soekarno kemudian memberi dukungan kepada kelompok-kelompok yang tidak puas, khususnya kaum Cina di Serawak yang khawatir akan kehilangan dominasinya. Banyak di antara orang Cina ini yang secara diam-diam melarikan diri dengan memasuki wilayah Indonesia di Provinsi Kalimantan Barat. Orang-orang ini kemudian dilatih dan dipersenjatai atas dukungan dari militer Indonesia. Melalui latihan ini mereka kemudian dimasukkan dalam Pasukan Rakyat Kalimantan Utara (PARAKU) dan Pasukan Gerakan Rakyat Serawak (PGRS). Kedua pasukan ini dipersenjatai dan bersama-sama dengan sukarelawan lainnya mereka melakukan infiltrasi ke wilayah Kalimantan Utara yang termasuk dalam wilayah Malaysia. Hingga akhir pemerintahan Soekarno, wilayah perbatasan Kalimantan Utara tetap menjadi medan pertempuran antara Indonesia dan Malaysia.

Setelah pergantian kepemimpinan di negeri ini, dari Soekarno ke Soeharto, program utama yang mendesak untuk diselesaikan pertama kali adalah konfrontasi dengan Malaysia. Soeharto mengutus Menteri Luar negeri Adam Malik untuk berunding dengan Menteri Luar Negeri Malaysia Tun Abdul Razak. Pertemuan yang dilangsungkan di Bangkok ini membuahkan hasil, dan akhirnya pada tanggal 11 Agustus 1966 secara resmi Soeharto menyatakan berakhirnya konfrontasi dengan Malaysia.

\section{MASALAH KAWASAN PERBATASAN ENTIKONG DEWASA INI}

Secara umum, menurut tim kajian kebijakan teknologi Pengembangan Wilayah BPPT, di kawasan perbatasan terdapat dua masalah besar, yakni pertama, permasalahan yang menyangkut kedaulatan bangsa dan negara; dan kedua kepentingan masyarakat 
perbatasan. Permasalahan pertama, tentang kedaulatan bangsa dan negara, lebih banyak didasarkan atas bergesernya patok tapal batas yang sebelumnya telah disepakati bersama. Pergeseran atas wilayah negara menjadi permasalahan yang cukup krusial. Adanya pergeseran patok-patok garis perbatasan atau bahkan hilang sama sekali patut menjadi perhatian kita bersama. Akibatnya, sebuah panitia survei dibentuk, dan menghasilkan konsensus adanya sepuluh permasalahan perbatasan Indonesia-Malaysia. ${ }^{16}$ Kesepuluh permasalahan ini dapat dikelompokkan menjadi beberapa bagian, yakni sebagai berikut.

- $\quad$ Tidak ada kesesuaian antara hasil survei tim Indonesia dan Malaysia.

- $\quad$ Penentuan beberapa wilayah berdasarkan Konvensi tahun 1928 pada kenyataannya di lapangan berbeda karena perbedaan penerapan jarak dan arah yang tidak sesuai antara kedua pihak.

- Watershed yang sudah ditetapkan berdasarkan survei tahun 1987/1988 hilang.

- $\quad$ Tugu yang berada di pulau Sebatik sudah berpindah tempat, dan tidak lagi berada pada posisi $4^{\circ} 20^{\prime \prime}$. Dalam hal ini pihak Republik Indonesia dirugikan. Menurut Direktur Administrasi Perbatasan Direktorat Jenderal Pemerintahan Umum Departeman Dalam Negeri, permasalahan pengukuran kembali dan penetapan patok-patok sesuai dengan konvensi tahun 1928, maupun hasil pengukuran ulang tahun 1987/1988 belum dapat disepakati oleh tim kedua negara.

- Sementara itu, permasalahan kedua menyangkut kepentingan masyarakat perbatasan, yang disebabkan oleh ketimpangan kondisi sosial ekonomi masyarakat di kawasan Kalimantan Barat. Permasalahan sosial ekonomi ini, akan merambat kepada permasalahan melunturnya rasa nasionalisme yang melihat deminian tingginya jaminan sosial bagi masyarakat Malaysia. ${ }^{17}$ Ketimpangan ini mengakibatkan pada keinginan sebagian warga untuk meninggalkan kewarganegaraannya berpindah menjadi warga negara Malaysia. Di samping itu, ketidakmerataan pembangunan yang dirasakan oleh masyarakat mengakibatkan rendahnya sumber daya manusia, yang berakibat pada kesenjangan sosial antarwarga masyarakat kawasan perbatasan maupun masyarakat pendatang. Demikian pula, pembangunan yang tidak melibatkan penduduk setempat hasilnya tidak menyentuh kebutuhan masyarakat secara langsung, bahkan akhirnya tidak

$\overline{16}$ Lihat Antara News tanggal 9 Desember 2007 (www. Antara.co.id/view/?i=119712-4600\&c=NAS\&s), diunduh pada tanggal 10 Mei 2010 pukul 15.00. Pandangan itu disampaikan pada acara Lokakarya Penataan Batas-Batas Daerah dan Pengembangan daerah Perbatasan Negara, yang diselenggarakan di Anyer, Banten, tanggal 8-9 Desember 2007.

17 Dari beberapa wawancara yang dilakukan oleh penulis di Balai Latihan Kerja Entikong, Kabupaten Sanggau, Kalimantan Barat tanggal 18 Mei 2010, mayoritas penduduk Entikong menginginkan pemerintah daerah dan pemerintah pusat memperhatikan penduduk wilayah perbatasan. Masalah mahalnya kebutuhan pokok seperti gas, bahan makanan sangat tinggi, karena tingginya beaya transportasi dari Pontianak sampai Entikong. Penduduk lebih senang membeli gas produk dari Petronas daripada produk Pertamina, karena adanya selisih harga yang cukup banyak. Mereka memilih membeli gas dari Petronas, karena selain ukurannya tepat, harganya juga hampir $1 / 2$ dari harga gas produksi Pertamina. 
dapat dimanfaatkan oleh penduduk setempat. Infrastruktur yang berupa jalan, tidak disesuaikan dengan konsep pertahanan keamanan, ataupun menunjang pengawasan di wilayah perbatasan.

- $\quad$ Berbagai pelanggaran terjadi, baik yang menyangkut untuk kepentingan pribadi maupun masyarakat banyak tidak dapat tertangani dengan baik. Tidak ada kepastian hukum yang dapat diandalkan oleh masyarakat setempat, sehingga berbagai pelanggaran terjadi di wilayah ini tanpa ada penanganan yang berarti dari pemerintah. Hal ini terjadi karena kurangnya informasi dan komunikasi serta kurang sadarnya masyarakat akan pentingnya memupuk rasa persaudaraan di antara masyarakat sebangsa dan setanah air. Semuanya akan dapat berjalan dengan lancar apabila disertai dengan uang sehingga keadilan tidak pernah menyentuh rakyat yang mayoritas berada di bawah garis kemiskinan.

- Permasalahan yang sangat mendasar inilah yang menyebabkan masyarakat kehilangan kesadaran akan pentingnya integrasi bangsa, pelestarian alam, saling menghargai sesama umat manusia. Kepentingan ekonomi dapat mengalahkan prinsip berbangsa dan bernegara yang akhirnya akan membahayakan integritas masyarakat di wilayah perbatasan. Berbagai barang ilegal dapat dengan mudah ditemukan di wilayah ini, bahkan secara nyata dilakukan di depan aparat yang berwenang. ${ }^{18}$

Selain itu, lemahnya infrastruktur, baik alat transportasi, jalan raya, komunikasi, lampu penerangan, tidak pernah mendapatkan perhatian yang serius dari pemerintah, sehingga sangat sering terjadi gangguan yang pada intinya merugikan masyarakat yang tinggal di wilayah perbatasan.

Demikian pula fasilitas kesehatan yang seharusnya sangat diperlukan oleh masyarakat, walaupun sudah menjangkau wilayah perbatasan, tetapi masih jauh dari memuaskan. Oleh karena itu, pelayanan kesehatan perlu diprioritaskan demi meningkatkan kesehatan dan kesejahteraan masyarakat perbatasan.

Hal yang selalu menjadi sorotan adalah terjadinya trafficking yang disebabkan oleh berbagai alasan, khususnya alasan ekonomi. Pekerjaan yang dijanjikan dari daerah asal mereka tidak sesuai dengan kenyataannya. Banyak di antara mereka yang dijual dan dijadikan pekerja seks komsersial (PSK). Di wilayah ini, penyakit masyarakat tidak hanya disebabkan oleh adanya trafficking, tetapi juga terjadi karena kebanyakan di antara pendatang yang belum mendapatkan pekerjaan kehabisan bekal, sehingga memerlukan

\footnotetext{
${ }^{18}$ Dari diskusi yang diselenggarakan dengan penduduk setempat, ada beberapa penduduk yang yakin bahwa garis batas wilayah negera antara Indonesia dan Malaysia tidak berada di Entikong, akan tetapi berada di antara Kabupaten Sanggau dan Entikong, sehingga, mereka beranggapan bahwa wilayah Entikong masuk dalam wilayah Negara Malaysia. (Diskusi dilakukan pada tanggal 18 Mei 2010 di Balai Latihan Kerja Entikong, Kabupaten Sanggau, Kalimantan Barat).
} 
biaya hidup. Sementara itu, mereka belum memperoleh mendapatkan pekerjaan sama sekali. Permasalahan sosial ini pun juga harus mendapatkan perhatian pemerintah baik pusat maupun daerah.

\section{PENUTUP}

Permasalahan yang ada di wilayah perbatasan tidak akan pernah kunjung selesai apabila tidak ditangani secara terpadu. Permasalahan pergeseran batas wilayah dapat disebabkan kedua belah pihak. Masyarakat tetangga yang memerlukan lahan demi eksploitasi bisnisnya tentunya akan berusaha untuk memperoleh lahan yang lebih luas. Sementara itu, batas wilayah dapat pula dilakukan oleh bangsa kita sendiri, yang merasa tidak memperoleh pelayanan yang cukup memadai dari pemerintah daerah setempat. Pemindahan patok batas negara sengaja dipindah dengan harapan untuk memperoleh kesejahteraan sosial yang lebih baik bila dibandingkan dengan apabila mereka menjadi warga negara Indonesia.

Bila ditinjau dari sejarahnya, masalah perbatasan di antara keduanya telah terjadi jauh sebelum kedua negara memperoleh kemerdekaannya. Tatkala kedua masyarakat masih terhubungkan dengan ikatan kekerabatan secara tradisional, permasalahan di antara keduanya relatif kecil atau bahkan hampir tidak ada sama sekali. Namun, apabila hubungan ini dikaitkan dengan kepentingan geopolitik antardua negara, permasalahannya menjadi sangat kompleks karena masing-masing penguasa bersitegang pada pendapat masing-masing yang mempertahankan hubungan kekuasaan di antara kedua negara. Permasalahan yang demikian itu hanya dapat diselesaikan melalui penyelesaian masalah secara bilateral maupun regional.

\section{DAFTAR ACUAN}

Arsip Khazanah Arsip Nasional Republik Indonesia

Staatsblad van Nederlandsch Indie over het jaar 1824 no. 19.

Staatsblad van Nederlandsch Indie over het jaar 1825 nomor 19.

Staatsblad van Nederlandsch Indie over het jaar 1849, nomor 40.

Staatsblad van Nederlandsch Indie over het jaar 1872 no. 95.

Staatsblad van Nederlandsch Indie over het jaar 1883 nommer 59.

Staatsblad van Nederlandsch Indie over het jaar 1892 no. 211.

Staatsblad van Nederlandsch Indie over het jaar 1916 no. 145.

Staatsblad van Nederlandsch Indie over het jaar 1930 no. 375.

Memorie van Overgave Kontroleur E. Werkman, Onderafdeeling Semitau, Sintang, Maart 1930, halaman 33, reel nomor 28, bundel MvO serie 1e.

Militaire Memorie van Patrollie gebied van het detachment in Bandjermasin, reel nomor 28, bundel MvO serie 1e.

Baud. Corpus Diplomaticum Neerlando Indicum. kontrak Sultan Kutai pada tanggal 11 
Oktober 1844.

Besluit van Gouverneur Generaal van Nederlandsch Indië 27 Januari 1916 no. 28.

Contract dd. 18 Augustus 1879 met opgave van de in het Rijk bestaande belastingen en omschrijving van het grondgebied Pontianak", dalam Indische Gids, tahun 1882.

Politiek verslag van Oost en Zuid Borneo over het jaar 1934-1940, reel nomor 8-9, bundel $\mathrm{MvO}$ serie $4 \mathrm{e}$.

Undang-Undang nomor 25 tahun 1956.

Undang-Undang Darurat nomor 10 tahun 1957.

Undang-Undang nomor 27 tahun 1959

Peraturan Pemerintah tahun 1996 nomor 39

Laporan Pemda Provinsi Kalimantan Barat yang berjudul Rencana Pembangunan dan Pengembangan Kawasan Perbatasan Kalimantan Barat, disampaikan oleh ketua Bappeda pada diskusi terbatas Pengembangan Kawasan Perbatasan Kalimantan, di Jakarta, 24 September 2001. Pontianak:Pemda Provinsi Kalimantan Barat.

\section{ENSIKLOPEDI}

Paulus, J. Encyclopaedie van Nederlandsch Indie, eerste deel's. Gravenhage: Martinus Nijhoff. 1918.

\section{KORAN}

Kedaulatan Rakyat, 17 Desember 2008.

Pontianak Pos, 28 Januari 2008.

Media Indonesia, 2 Desember 2008

Media Indonesia, 3 Desember 2008

Media Indonesia, 26 Februari 2009

Kompas, 9 April 2008

Kompas, 23 Januari 2009

Kompas, 23 Januari 2009

Kompas, 7 Februari 2009

Kompas, 13 Februari 2009

Kompas, 14 Februari 2009

\section{BUKU DAN MAJALAH}

Anonim. "Verslag van de Residentie Borneo's Westkust, 1827-1829, van den toenmaligen. 1871.

Anonim. “Borneo voor Engeland?”, dalam Indische Gids, jilid I. 1881.

Anonim. "De grenzen van ons gebied op Borneo", dalam Indische Gids, Jilid I. 1882.

Anonim. "Het grens tusschen het gebied van Nederland en dat van de North Borneo 
Company" dalam Indische Gids, jilid II. 1888.

Anonim. "De Borneo kwestie (grensregeling) in de Staten Generaal", dalam Indische Gids, Jilid I. 1882.

Anonim. "Contract dd. 4 Maart 1882 met voorlopige opgave der grenzen van het landschap Sanggouw en opgave van de daar bestaande belastingen", dalam Tijdschrift voor Nederlandsch Indie, jilid I. 1884.

Anonim. "Is Nederland te zwak om Indie te besturen?", dalam Indische Gids, Jilid I. 1889.

Anonim. "Het Borneo Traktaat" dalam Tijdschrift voor Nederlandsch Indie, jilid II. 1891.

Anonim. "De grensregeling in Noord Borneo", dalam Tijdschrift voor Nederlandsch Indie, Jilid II. 1891.

Boer, P.A.C, P.C. Benjamins and M.T.A. Scherp, De luchtstrijd om Indie; Operaties van de Militaire Luchtbvaart KNIL in de periode december 1941 tot februari 1942.Houten: Van Holkema en Warendorf. 1990.

Clemens, A.H.P. dan J.Th. Lindblad. Het belang van de buitengewesten. Economische expansie en koloniale staatsvorming in de Buitengewesten van Nederlands Indie 1870-1942. Amsterdam: NEHA. 1989.

Christie, Clive. Ideology and Revolution in Southeast Asia 1900-980. Cornwall: Curzon. 2001.

Cross, J.P. A face like a chicken backside: an unconventional soldier in Malaya and Borneo 1948-1971. London: Greenhill Books. 1996.

Damste,H.T. “Atjeh Historie” dalam Koloniaal Tijdschrift. 1916.

Dobby, E.H.G. Southeast Asia .London: University of London Press. 1964.

Drooglever, J. Officiele Bescheiden betreffende de Nederlands-Indonesische betrekkingen 1945-1950, twintigste deel .'s Gravenhage: Martinus Nijhoff. 1991.

Hamid, Sri Handoyo Mukti, Tien Widianto. Kawasan Perbatasan Kalimantan: Permasalahan dan Konsep Pengembangan. Jakarta: Badan Pengkajian dan Penerapan Teknologi. 2004.

Harrison, Brian. South-East Asia a Short History. London: McMillan \& Co. 1954.

Jones, Barbara Wittingham. "The Malino conference and after" dalam Asiatic Review, jilid 42. 1946.

Kielstra, EB. “Bijdragen tot de geschiedenis van Borneo's Westkust Afdeeling” dalam Indische Gids, Jilid I. 1850.

Kielstra, E.B. “De opstand der Chineezen in Serawak (1857)" dalam Tijdspiegel, tahun jilid II. 1889.

Kielstra, E.B. "De ondergang van het Bandjermassinsche Rijk" dalam Indische Gids, Jilid I. 1890.

Kielstra, E.B. De Vestiging van het Nederlandsche Gezag in den Indischen Archipel. Haarlem: De Erven F. Bohn. 1920. 
Knaap, Gerrit dan Heather Sutherland. Monsoon Traders: Ship, Skippers and Commodities in Eighteenth Century Makassar. Leiden: KITLV Press. 2004.

Lancker, A.F. "Herinneringen aan Borneo", dalam Mars et Historia, jilid 14. 1980.

Mallinckrodt, J. Adatrecht van Borneo, deel 1. Leiden: M. Dubbeldeman. 1928.

Norie,J.W. Naval Gazetteer, Biographer and Chronologists. London: JW Noorie \& co. 1827.

Nurcahyani, Lisyawati, dan Salmon Batualo. Identitas Suku di Perbatasan: Studi Kasus di Dusun Aruk, Desa Sebunga, Kecamatan Sajingan Besar, Kabupaten Sambas. Kalimantan Barat: Balai Kajian Sejarah dan Nilai Tradisional Pontianak. 2007.

Nurcahyani, Lisyawati, dan Salmon Batualo. Perdagangan Lintas Batas dan Dampaknya Bagi Masyarakat: Tinjauan Sejarah dan Budaya di Kecamatan Entikong, Kab. Sanggau. Pontianak: Balai Kajian Sejarah dan Nilai Tradisional. 2008.

Peattie, Mark, R. Ishiwara Kanji and Japan's Confrontation with the West.Pincenton: Princenton University Press. 1973.

Pelras, Christian. The Bugis. Oxford: Blackwell. 1966.

Pluvier, Jan. Southeast Asia From Collonialism to Independence.Kuala Lumpur: Oxford University Press. 1974.

Reid, Anthony. The Contest for North Sumatra: Acheh, the Netherlands and Britain 18581898. Kuala Lumpur: University of Malaya Press. 1969.

Resident J.D. van den Dungen Gronovius", dalam Tijdschrift voor Nederlandsch Indie, jilid I.

Robide van der Aa, PJBC. "De aanspraken van Solok op Noord-Oost Borneo" dalam Indische Gids, tahun 1882, jilid I. 1882.

Saham, Junid. British Industrial Investment in Malaysia 1963-1971. Kuala Lumpur: Oxford University Press. 1980.

Senn van Basel, W.H. "De Chineezen op Borneo's Westkust" dalam Tijdschrift voor Nederlandsch Indie, tahun 1875, jilid I. 1875.

Serafin, R.P. Dany Sanusi OSC. "Entikong: Perbatasan Rawan Perdagangan Manusia", dimuat dalam www.misifica.net. tanggal 11 Agustus 2008. 2008.

Shafie, Mohamad Tan Sri Gazali. Ghazali Shafie's Memoir on the Formation of Malaysia. Bangi: Penerbit Universiti Kebangsaan Malaysia. 1998.

Son van Bassel, W.M. "De Chineezen op Borneo's Westkust", dalam Tijdschrift voor Nederlandsch Indie, , jilid 1. 1875.

Stapel, F.W. Geschiedenis van Nederlandsch Indie, deel V. Amsterdam: N.V. Uitgeversmaatschappij Joost van den Vondel. 1940.

Sumardi, Ade, Ini Chandra Sasih. Identitas Suku di Perbatasan. Studi Kasus di Desa Jasa Kecamatan Ketungau, Kabupaten Sintang. Kalimantan barat: Balai Kajian Sejarah dan Nilai Tradisional Pontianak. 2007.

Tim Peneliti. Perubahan Sosial Masyarakat Perbatasan: Studi Kasus di Wilayah Kalimantan 
Barat. Laporan Penelitian. Pontianak: Fakultas Ilmu-Ilmu Sosial Universitas Tanjung Pura. 1993.

Wijnen,R. "Protes van Gijsberts", dalam Indische Tijdschrift, Edisi 22 September 1891, nomor 104. 1891.

Wulandari, Triana, dkk. Sejarah Wilayah Perbatasan Batam-Singapura 1824-2009. Satu Selat Dua Nahkoda. Jakarta: Gramata Publishing. 2009.

Wulandari, Triana, dkk. Sejarah Wilayah Perbatasan Entikong-Malaysia 1845-2009. Satu Ruang Dua Tuan. Jakarta: Gramata Publishing. 2009.

Velden, D. Van. De Japanse interneringskampen voor burgers gedurende de tweede Wereldoorlog.Franeker: Uitgeverij Wever BV. 1974.

Veth, P. J. "Fragmenten van eene reis op de Westkust van Borneo in 1830" dalam Tijdschrift voor Nederlandsch Indie, Jilid II. 1867. 